\title{
OPEN Molecular simulation of gases competitive adsorption in lignite and analysis of original $\mathrm{CO}$ desorption
}

Jing Zhang ${ }^{1,2 \bowtie}$, Jiren Wang ${ }^{1,2}$, Chunhua Zhang ${ }^{1,2}$, Zongxiang $\mathrm{Li}^{1,2}$, Jinchao Zhu ${ }^{1,2}$ \& Bing $\mathrm{Lu}^{1,2}$

To study the adsorption characteristics of $\mathrm{CO}, \mathrm{CO}_{2}, \mathrm{~N}_{2}, \mathrm{O}_{2}$, and their binary-components in lignite coal, reveal the influence of $\mathrm{CO}_{2}$ or $\mathrm{N}_{2}$ injection and air leakage on the desorption of $\mathrm{CO}$ in goafs, a lignite model $\left(\mathrm{C}_{206} \mathrm{H}_{206} \mathrm{~N}_{2} \mathrm{O}_{44}\right)$ was established, and the supercell structure was optimized under temperatures of 288.15-318.15 K for molecular simulation. Based on molecular dynamics, the Grand Canonical Monte Carlo method was used to simulate the adsorption characteristics and the Langmuir equation was used to fit the adsorption isotherms of gases. The results show that for single-components, the order of adsorption capacity is $\mathrm{CO}_{2}>\mathrm{CO}>\mathrm{O}_{2}>\mathrm{N}_{2}$. For binary-components, the competitive adsorption capacities of $\mathrm{CO}_{2}$ and $\mathrm{CO}$ are approximate. In the low-pressure zone, the competitive adsorption capacity of $\mathrm{CO}_{2}$ is stronger than that of $\mathrm{CO}$, and the $\mathrm{CO}$ is stronger than $\mathrm{N}_{2}$ or $\mathrm{O}_{2}$. From the simulation, it can be seen that $\mathrm{CO}_{2}, \mathrm{~N}_{2}$ or $\mathrm{O}_{2}$ will occupy adsorption sites, causing $\mathrm{CO}$ desorption. Therefore, to prevent the desorption of the original $\mathrm{CO}$ in the goaf, it is not suitable to use $\mathrm{CO}_{2}$ or $\mathrm{N}_{2}$ injection for fire prevention, and the air leakage at the working faces need to be controlled.

$\mathrm{CO}$ is a toxic and harmful gas in a coal mine, which affects the health of miners and restricts the production of coal mines ${ }^{1}$. For the generation of $\mathrm{CO}$, it is generally considered that $\mathrm{CO}$ comes from the oxidation and spontaneous combustion of coal or mine explosion ${ }^{2,3}$, and no attention has been paid to the desorption of original CO in coal. Therefore, $\mathrm{CO}$ is widely used as an index gas to judge spontaneous combustion in many coal mines of China $^{4}$. However, in recent years, it has been proved that spontaneous combustion of coal is not the only source of CO. In many low-rank coal mines, $\mathrm{CO}$ continues to exceed the standard and no signs of spontaneous combustion have been found. The literature shows the $\mathrm{CO}$ comes from the coal formation stage in these mines, instead of oxidation or spontaneous combustion ${ }^{5}$. Affected by mining, part of residual broken coal is left in the goaf, and the $\mathrm{CO}$ can desorb under various conditions and spread to the working face, which brings great difficulties to coal mine work. Coal is a porous material with surface area and pore volume, which provides conditions for gas adsorption. Therefore, understanding the $\mathrm{CO}$ adsorption mechanism and the adsorption competitive relationship between $\mathrm{CO}, \mathrm{O}_{2}, \mathrm{~N}_{2}$, and $\mathrm{CO}_{2}$ is of great significance to the control of $\mathrm{CO}$ in working faces.

Gases present in coal mainly enter through physical adsorption. The adsorption capacity of gas in coal is mainly affected by coal $\mathrm{rank}^{6}$, pore structure ${ }^{7,8}$, pressure and temperature ${ }^{9}$, moisture content ${ }^{10}$, functional groups ${ }^{11}$. Many scholars have made studies on coal adsorption gases. Tang et al. ${ }^{12}$ and Meng et al.$^{13}$ studied the adsorption characteristics of coal to supercritical $\mathrm{CO}_{2}$ and verified the adaptability of the Langmuir equation to the fitting of coal adsorption isotherms, and the adsorption form of supercritical $\mathrm{CO}_{2}$ was analyzed. Zhang et al. ${ }^{14}$ and Wu et al. ${ }^{15}$ used a Monte Carlo-based molecular simulation method to study the effect of moisture content on coal adsorption of methane. Zhou et al. ${ }^{16}$ used molecular simulation methods to study the competitive adsorption characteristics of $\mathrm{CO}_{2} / \mathrm{CH}_{4} / \mathrm{H}_{2} \mathrm{O}$ on lignite, while $\mathrm{Yu}$ et al. ${ }^{17}$ further studied the competitive adsorption characteristics of $\mathrm{CO}_{2} / \mathrm{CH}_{4} / \mathrm{H}_{2} \mathrm{O}$ in different coal ranks. Gao et al. ${ }^{18}$ studied the adsorption characteristics of $\mathrm{CO}_{2} / \mathrm{CH}_{4} / \mathrm{N}_{2} / \mathrm{H}_{2} \mathrm{O}$ single-components and multi-components on lignite. For the adsorption of $\mathrm{CO}$ on coal, related research is relatively scarce. Zhu et al. ${ }^{19}$ conducted experiments to study the generation and release laws of the original CO in coal seams and verified the existence of other CO sources besides spontaneous combustion. Zhang et al. ${ }^{20}$ also analyzed the $\mathrm{CO}$ formation and release rules in mines without spontaneous combustion, and conducted a targeted study on the influence of inertinite and vitrinite on $\mathrm{CO}$ adsorption in different coal ranks.

${ }^{1}$ College of Safety Science \& Engineering, Liaoning Technical University, Fuxin 123000, Liaoning, China. ${ }^{2}$ Key Laboratory of Mine Thermodynamic Disaster \& Control of Ministry of Education, Huludao 125105, Liaoning, China. ${ }^{\varpi}$ email: zhangj163Intu@163.com 


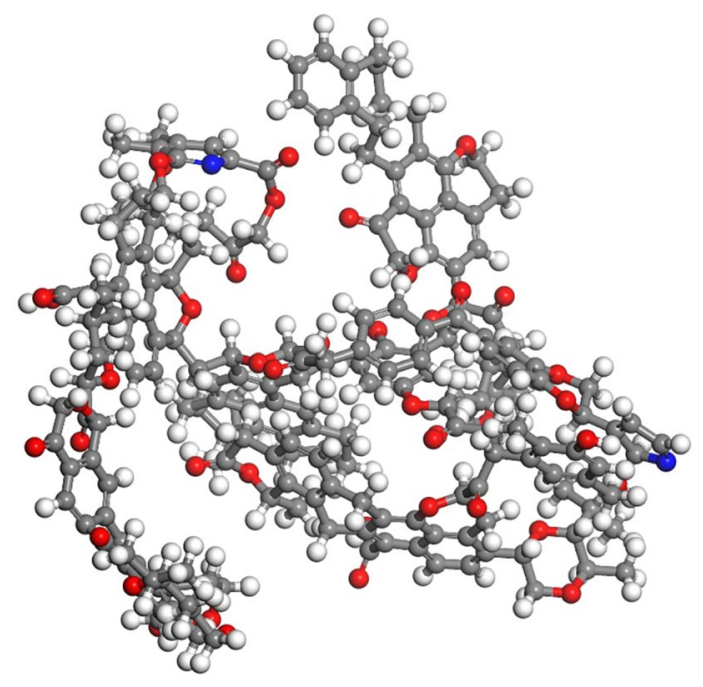

Figure 1. The basic unit of lignite molecular $\mathrm{C}_{206} \mathrm{H}_{206} \mathrm{~N}_{2} \mathrm{O}_{44}$ (C: grey; O: red; $\mathrm{N}$ : blue; $\mathrm{H}$ : white).

Sharma et al. ${ }^{21}$ investigated the shale gas adsorption and diffusion in inorganic nanopores by molecular simulation. Lin et al. ${ }^{22-25}$ studied methane displacement and shale gas molecular dynamics simulation and obtained adsorption characteristics of the gas on graphite and carbon nanotubes, the law of entropy change and enthalpy change, and free energy change in the process of adsorption or displacement. Wang et al. ${ }^{26}$ discussed the direct air capture of low concentration $\mathrm{CO}_{2}$ by $5 \mathrm{~A}$ zeolite adsorbent bed combined GCMC and FVM method. Li et al. ${ }^{27,28}$ discussed the superior selective $\mathrm{CO}_{2}$ adsorption of $\mathrm{C}_{3} \mathrm{~N}$ pores by GCMC and DTF simulations.

The research of scholars mainly focused on the competitive adsorption of $\mathrm{CH}_{4}, \mathrm{~N}_{2}$, and $\mathrm{CO}_{2}$ by experiments or molecular simulation methods. A few scholars have studied the adsorption characteristics of $\mathrm{CO}$ in coal through experiments but did not use molecular simulation to further study the mechanism and the adsorption competitive relationship of $\mathrm{CO}$ with other gases on lignite molecules. Here, by using molecular simulation technology based on molecular mechanics and dynamics, it is found that in the mining process, the leakage of fresh air and the injection of fire-prevention gases in the goaf are the reasons for the desorption and diffusion of the original $\mathrm{CO}$. To more clearly compare the adsorption competitive characteristics and capacities of $\mathrm{CO}$ and other gases in lignite, this paper establishes supercell structures of lignite and adds $\mathrm{CO}$ to the adsorption simulation system for the first time, simulating $\mathrm{CO}, \mathrm{CO}_{2}, \mathrm{~N}_{2}, \mathrm{O}_{2}$ and their binary-components. The disadvantages of traditional fire-prevention work for the mines with the original $\mathrm{CO}$ desorption are analyzed. The results of this research have played an important guiding role in $\mathrm{CO}$ prevention and control in coal mines.

\section{Simulation condition}

Establishment of the coal model. The basic unit model of lignite coal $\left(\mathrm{C}_{206} \mathrm{H}_{206} \mathrm{~N}_{2} \mathrm{O}_{44}\right)^{29}$ is established as shown in Fig. 1. The literature shows that the structure of coal is closely related to temperature, so the normal working temperatures $(288.15,298.15,303.15$, and $313.15 \mathrm{~K})$ of the mine is selected, and the 3D Triclinic Lattice type with fixing angle $\left(\alpha: 90^{\circ}, \beta: 90^{\circ}, \gamma: 90^{\circ}\right)$ is used. By using the "Forcite" module, the coal unit cell is optimized and annealed, and the charge balance method (QEq) is used to calculate the charge distribution. The unit cell size is $a=41.80 \AA, b=39.46 \AA, c=37.71 \AA$. Considering that the adsorption of gas molecules may lead to a pore-blocking phenomenon with pore volume decreases in reality ${ }^{30}$, a probe with a radius of $1.6 \AA$ was used to determine the differences of pore structures. In the simulation, whether the adsorbed molecules cause a poreblocking phenomenon and reduce the adsorption capacity is controlled by the simulation soft. The Connolly free volume of the optimal supercells at four temperatures are $46,245.14 \AA^{3}, 46,321.85 \AA^{3}, 46,206.47 \AA^{3}$, and $46,266.11$ $\AA^{3}$, respectively, and the surface areas are $7633.82 \AA^{2}, 7603.38 \AA^{2}, 7663.65 \AA^{2}$, and $7195.66 \AA^{2}$, respectively. As shown in Fig. 2, it can be seen that temperature has a significant influence on the structure of coal molecular unit cells ${ }^{31}$. Therefore, it is necessary to optimize annealing at different temperatures. When the temperature reaches $308.15 \mathrm{~K}$, the supercell structure has the smallest Connolly free volume and the largest surface area.

Here, the adsorption of $\mathrm{CO}, \mathrm{CO}_{2}, \mathrm{O}_{2}, \mathrm{~N}_{2}$, and their binary-components were simulated on the lignite. The adsorption characteristics were determined. By comparing the adsorption characteristics and capacity of $\mathrm{CO}$ and other gases, the desorption mechanism of $\mathrm{CO}$ and the influences of other gases were analyzed in mines without spontaneous combustion danger.

Relationship between fugacity and pressure. Fugacity of single-components. The temperatures are specified as $288.15,298.15,308.15$, and $318.15 \mathrm{~K}$, respectively, and the pressures are between 0 and $10 \mathrm{MPa}$. The conversion between pressure and fugacity is realized by using the Peng-Robinson formula. The physical properties of the four gases are shown in Table 1. The relationship between the fugacity of each gas and the pressure is shown in Fig. 3, where the fugacity coefficient is the ratio of fugacity to pressure. 


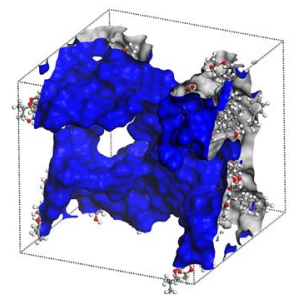

(a) $288.15 \mathrm{~K}$

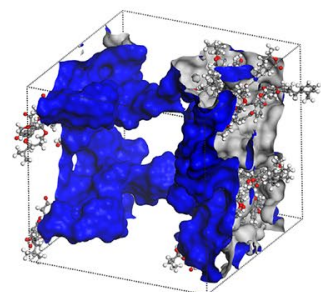

(b) $298.15 \mathrm{~K}$

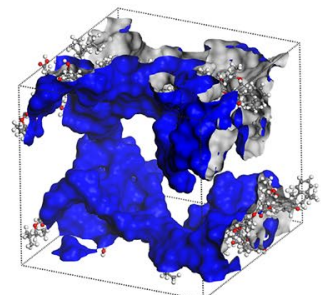

(c) $308.15 \mathrm{~K}$

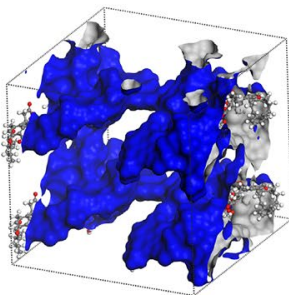

(d) $318.15 \mathrm{~K}$

Figure 2. Supercell structures and Connolly surfaces of lignite at different temperatures (Blue areas are Connolly surfaces).

\begin{tabular}{|l|r|r|r|r|}
\hline Physical properties & \multicolumn{1}{|c|}{$\mathbf{C O}$} & \multicolumn{1}{c|}{$\mathbf{C O}_{2}$} & \multicolumn{1}{|c|}{$\mathbf{N}_{2}$} & \multicolumn{1}{c|}{$\mathbf{O}_{2}$} \\
\hline Molar mass $M /\left(\mathrm{g} \mathrm{mol}^{-1}\right)$ & \multicolumn{1}{|c|}{28.01} & \multicolumn{1}{|c|}{44.01} & \multicolumn{1}{c|}{28.01} & 32.00 \\
\hline Critical temperature $T_{c} / \mathrm{K}$ & 132.86 & 304.12 & 126.19 & 154.58 \\
\hline Critical pressure $P_{c} / \mathrm{MPa}$ & 3.49 & 7.38 & 3.40 & 5.04 \\
\hline Acentric factor & 0.05 & 0.22 & 0.04 & 0.022 \\
\hline
\end{tabular}

Table 1. Physical properties of the gases.

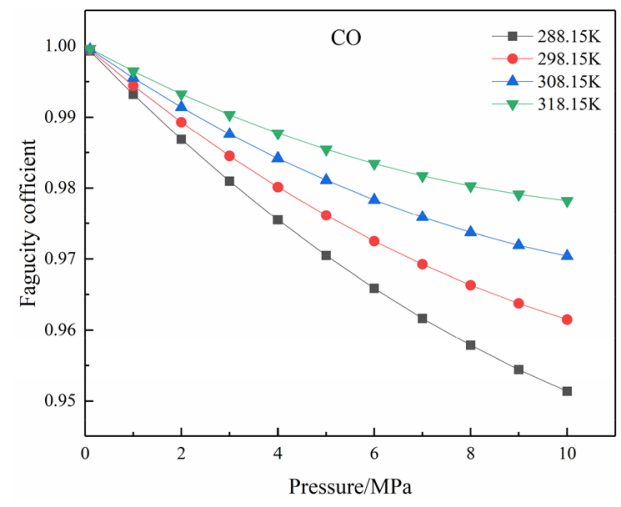

(a) $\mathrm{CO}$

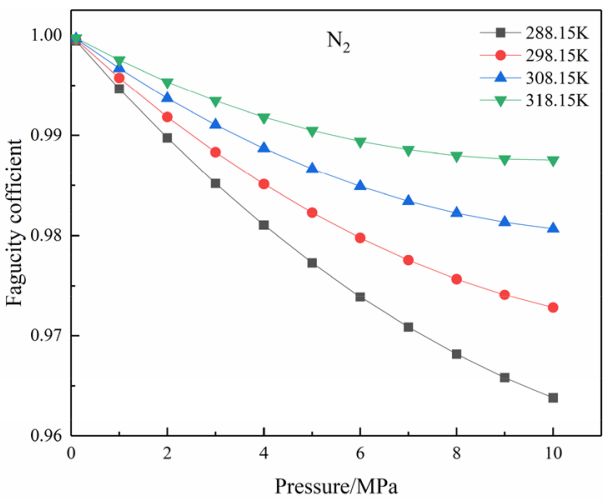

(c) $\mathrm{N}_{2}$

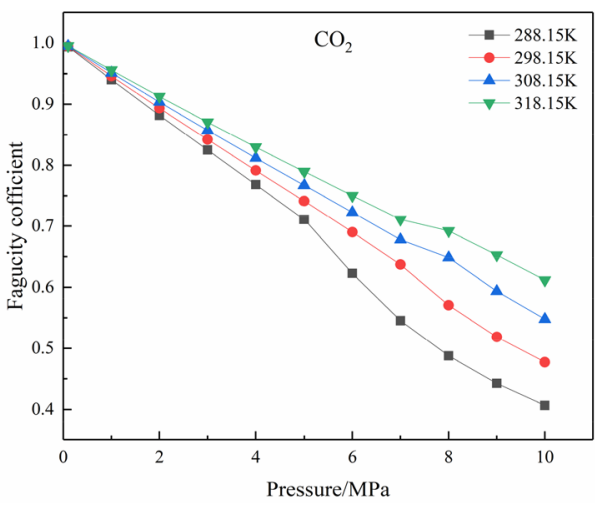

(b) $\mathrm{CO}_{2}$

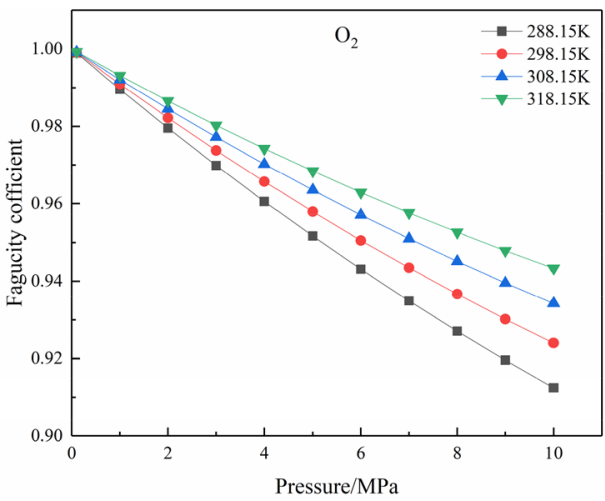

(d) $\mathrm{O}_{2}$

Figure 3. The relationship between the fugacity coefficient and pressure of single-components at different temperatures. 


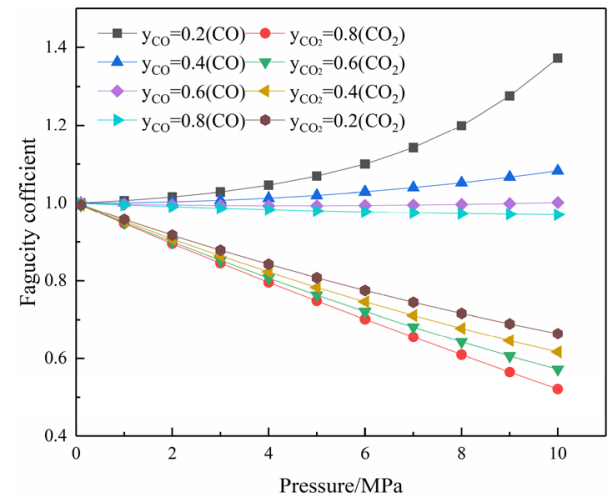

(a) $\mathrm{CO} / \mathrm{CO}_{2}$

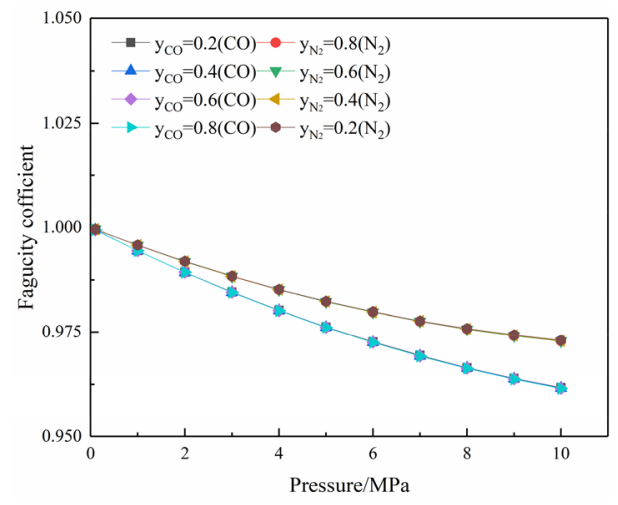

(b) $\mathrm{CO} / \mathrm{N}_{2}$

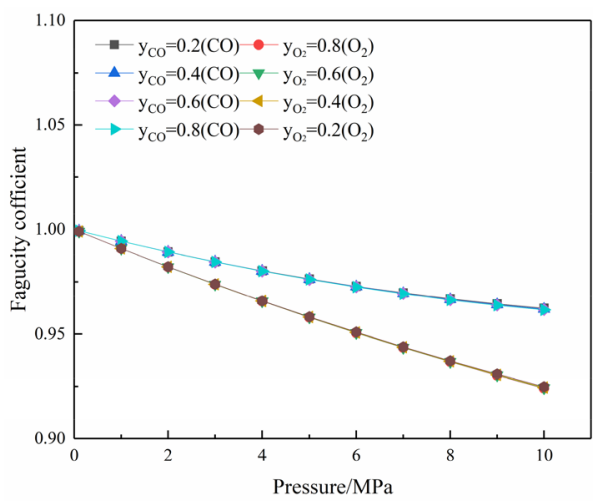

(c) $\mathrm{CO} / \mathrm{O}_{2}$

Figure 4. Relationship between fugacity coefficient and pressure of binary-components at $298.15 \mathrm{~K}$.

The fugacity of a single-component is mainly affected by temperature and pressure. Under the same temperature condition, the fugacity coefficient decreases with the increase of pressure; under the same pressure condition, the fugacity coefficient increases with the increase of temperature. In the pressures of 0-10 MPa and the temperatures of $288.15-318.15 \mathrm{~K}$, the fugacity coefficients of $\mathrm{CO}, \mathrm{O}_{2}$, and $\mathrm{N}_{2}$ have relatively small changes, between 0.9 and 1.0; while the fugacity coefficient of $\mathrm{CO}_{2}$ changes greatly, between 0.4 and 1.0. This change is mainly due to the high critical temperature of $\mathrm{CO}_{2}$, which is $304.13 \mathrm{~K}$. Therefore, at 288.15 and $298.15 \mathrm{~K}$, when the pressure exceeds critical pressure $7.38 \mathrm{MPa}, \mathrm{CO}_{2}$ changes from a gas to a liquid, the trend of fugacity coefficient is slightly higher than the original trend; At $308.15 \mathrm{~K}$ and $318.15 \mathrm{~K}$, when the pressure exceeds critical pressure $7.38 \mathrm{MPa}, \mathrm{CO}_{2}$ gradually enters the supercritical state, the trend of fugacity coefficient is slightly lower than the original trend. The order of the fugacity coefficient of various gases affected by temperature and pressure is $\mathrm{CO}_{2}>\mathrm{O}_{2}>\mathrm{CO}>\mathrm{N}_{2}$.

Fugacity of binary-components. At $298.15 \mathrm{~K}$, the fugacity and pressure relationship of the binary-components of $\mathrm{CO}$ with other gases are shown in Fig. 4. According to the calculation of the binary-components Peng-Robinson formula ${ }^{32}$, it can be found that when $\mathrm{CO}$ and $\mathrm{CO}_{2}$ are mixed, the fugacity coefficients are greatly affected by the molar ratio. Under a condition of a certain molar ratio, with the increase of pressure, the fugacity coefficient of $\mathrm{CO}$ increases, and the fugacity coefficient of $\mathrm{CO}_{2}$ decreases; under a condition of the same pressure, with the increase of temperature, the fugacity coefficients of $\mathrm{CO}$ and $\mathrm{CO}_{2}$ both decrease. This is because the $\mathrm{CO}_{2}$ fugacity coefficient is much more affected than $\mathrm{CO}$ in the same pressure and temperature. While $\mathrm{CO}$ and $\mathrm{O}_{2}$ or $\mathrm{N}_{2}$ form a mixture, the molar ratio has little effect on the fugacity coefficient, and the fugacity point diagrams of the gas at different ratios coincide.

\section{Results and discussion}

The "Sorption" module in the molecular simulation software was used to simulate the adsorption of four gases on the lignite coal molecular supercell structure. Based on the GCMC (Grand Classic Monte Carlo) method ${ }^{33}$, the adsorption isotherms of single-components and binary-components at different temperature conditions are obtained. The "Sorption" module determines the adsorption position based on the annealing principle, selects the Metropolis algorithm, selects the Dreiding force field ${ }^{34}$ under the charge balance method (QEq) $)^{35}$, selects the Ewald \& Group method ${ }^{36}$ to calculate the electrostatic force, the Atom-based Method ${ }^{36}$ to calculate van 


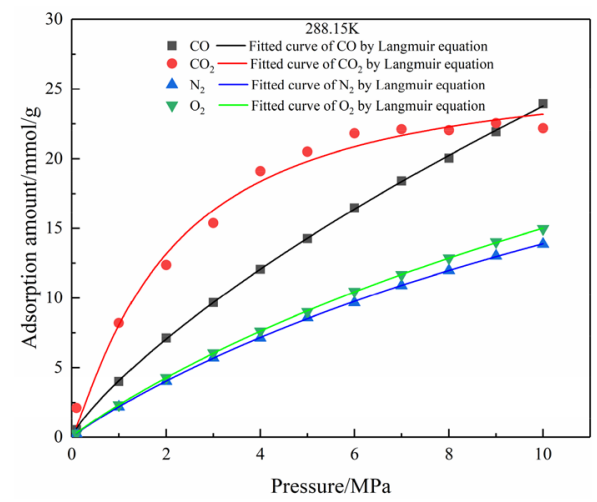

(a) $288.15 \mathrm{~K}$

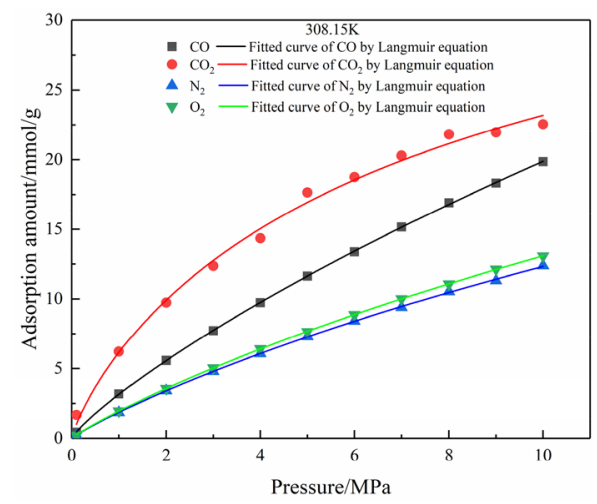

(c) $308.15 \mathrm{~K}$

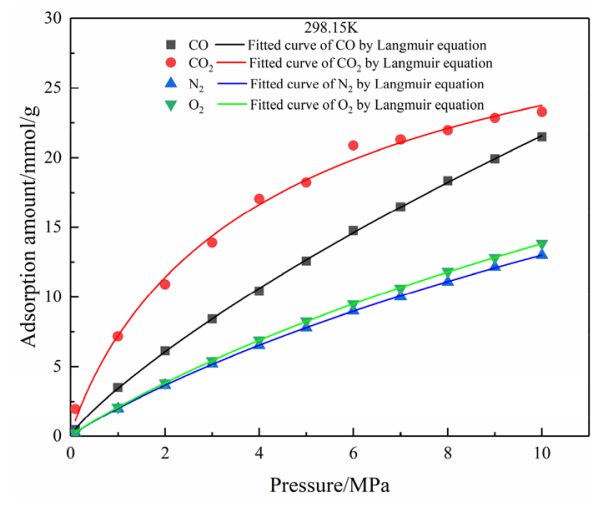

(b) $298.15 \mathrm{~K}$

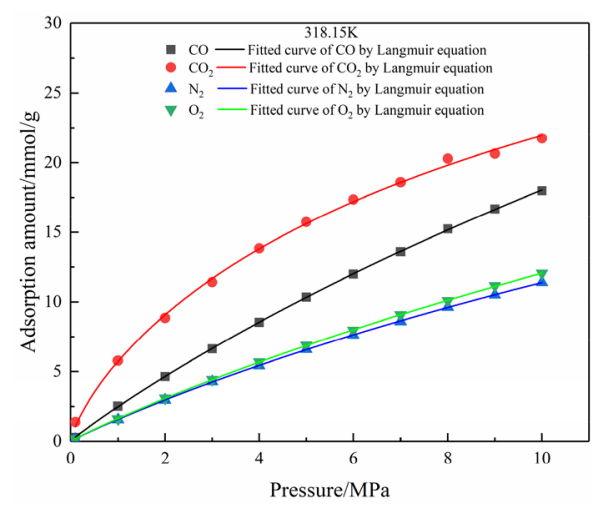

(d) $318.15 \mathrm{~K}$

Figure 5. Adsorption isotherms of $\mathrm{CO}, \mathrm{CO}_{2}, \mathrm{~N}_{2}$, and $\mathrm{O}_{2}$ at different temperatures.

der Waals force. Determine the number of balance steps as $10^{6}$ and the number of production steps as $2^{\star} 10^{6}$ to obtain accurate balance data through the sampling method. When C/D Ratio in the logfile is close to 1, it can be considered that the simulation is accurate.

The unit of adsorption capacity obtained from the simulation results is [average molecules/cell], which is converted to $[\mathrm{mmol} / \mathrm{g}]$ by Eq. (1):

$$
\text { Uptake }(\mathrm{mmol} / \mathrm{g})=\frac{\text { Loading molecules }}{M_{\text {rcell }}(\mathrm{g} / \mathrm{mol})} \times 10^{3}
$$

where $M_{\text {rcell }}$ is the relative molecular mass of the adsorbent in the unit cell.

Single-component adsorption isotherms of $\mathrm{CO}, \mathrm{CO}_{2}, \mathrm{~N}_{2}$, and $\mathrm{O}_{2}$. It shows the adsorption isotherms of $\mathrm{CO}, \mathrm{CO}_{2}, \mathrm{~N}_{2}$, and $\mathrm{O}_{2}$ at 288.15-318.15 $\mathrm{K}$ and 0-10 MPa in Fig. 5. The data is fitted to the adsorption isotherm by the Langmuir equation ${ }^{37,38}$. The Langmuir fitting formula is:

$$
y=a b x /(1+b x)
$$

where $a$ represents the limit adsorption capacity of the adsorbate when the pressure tends to infinity, $\mathrm{mmol} / \mathrm{g} ; b$ is the adsorption constant, $\mathrm{MPa}^{-1}$. The simulation results are shown in Table 2, where $\mathrm{R}^{2}$ is the fitting accuracy.

Under the same temperature and pressure conditions, the order of the adsorption capacity of different gases from large to small is $\mathrm{CO}_{2}>\mathrm{CO}>\mathrm{O}_{2}>\mathrm{N}_{2}$ (this sequence conforms to the general situation in 0-10 MPa, but at $288.15 \mathrm{~K}$, after $9.5 \mathrm{MPa}$, the $\mathrm{CO}$ adsorption capacity larger than $\mathrm{CO}_{2}$ ), as shown in Fig. 5. The adsorption capacity of different gases is related to their physical properties. $\mathrm{CO}_{2}, \mathrm{O}_{2}$, and $\mathrm{N}_{2}$ are non-polar molecules, and the adsorption capacity is positively related to the critical temperature and critical pressure of the three gases, as shown in Table 1, while CO is a polar molecule with a coordination bond in the molecule, so its adsorption capacity is stronger than $\mathrm{N}_{2}$ and $\mathrm{O}_{2}$, while the critical temperature of $\mathrm{CO}_{2}$ is much greater than that of $\mathrm{CO}$, which is dominant. Finally, the order of adsorption capacity of $\mathrm{CO}_{2}>\mathrm{CO}>\mathrm{O}_{2}>\mathrm{N}_{2}$ was got.

Besides, comparing the $\mathrm{CO}$ adsorption capacity at different temperatures, it can be found that with the temperature increasing, the adsorption capacity is decreasing, which is also adaptable in the adsorption characteristics of other gases. It can be seen that the oxidation of the residual coal in the goaf will not only produce CO 


\begin{tabular}{|l|l|l|l|l|}
\hline Temperature/K & Gas & $\mathbf{a}$ & $\mathbf{b}$ & $\mathbf{R}^{2}$ \\
\hline \multirow{5}{*}{288.15} & $\mathrm{CO}$ & 61.93359 & 0.06107 & 0.99854 \\
\cline { 2 - 5 } & $\mathrm{CO}_{2}$ & 28.96694 & 0.41977 & 0.98319 \\
\cline { 2 - 5 } & $\mathrm{N}_{2}$ & 36.32608 & 0.06158 & 0.99976 \\
\cline { 2 - 5 } & $\mathrm{O}_{2}$ & 41.26188 & 0.05677 & 0.99976 \\
\hline \multirow{5}{*}{298.15} & $\mathrm{CO}$ & 64.33922 & 0.04970 & 0.99886 \\
\cline { 2 - 5 } & $\mathrm{CO}_{2}$ & 32.34059 & 0.26936 & 0.99339 \\
\cline { 2 - 5 } & $\mathrm{N}_{2}$ & 36.94775 & 0.05390 & 0.99970 \\
\cline { 2 - 5 } & $\mathrm{O}_{2}$ & 40.77887 & 0.05097 & 0.99980 \\
\hline \multirow{5}{*}{308.15} & $\mathrm{CO}_{5}$ & 59.87083 & 0.04898 & 0.99901 \\
\cline { 2 - 5 } & $\mathrm{CO}_{2}$ & 34.76296 & 0.19456 & 0.99268 \\
\cline { 2 - 5 } & $\mathrm{N}_{2}$ & 37.32935 & 0.04887 & 0.99952 \\
\cline { 2 - 5 } & $\mathrm{O}_{2}$ & 41.12169 & 0.04631 & 0.99969 \\
\hline & $\mathrm{CO}_{15}$ & 67.21716 & 0.03651 & 0.99984 \\
\cline { 2 - 5 } & $\mathrm{CO}_{2}$ & 33.85058 & 0.17696 & 0.99609 \\
\cline { 2 - 5 } & $\mathrm{N}_{2}$ & 40.78997 & 0.03860 & 0.99986 \\
\cline { 2 - 5 } & $\mathrm{O}_{2}$ & 46.83634 & 0.03454 & 0.99985 \\
\hline
\end{tabular}

Table 2. Langmuir fitting parameters of single-component adsorption at different temperatures.

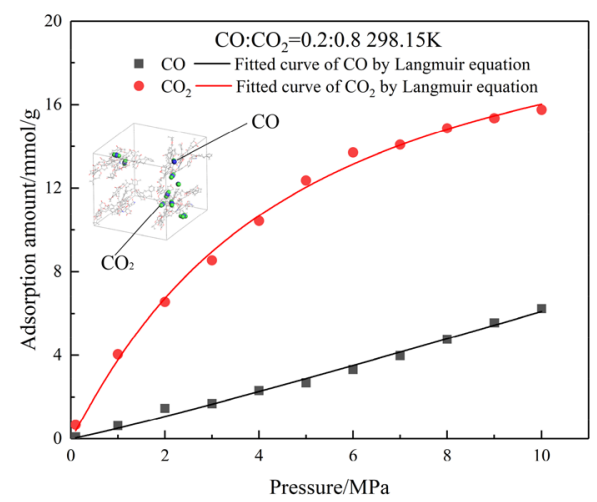

(a) $\mathrm{CO}: \mathrm{CO}_{2}=0.2: 0.8$

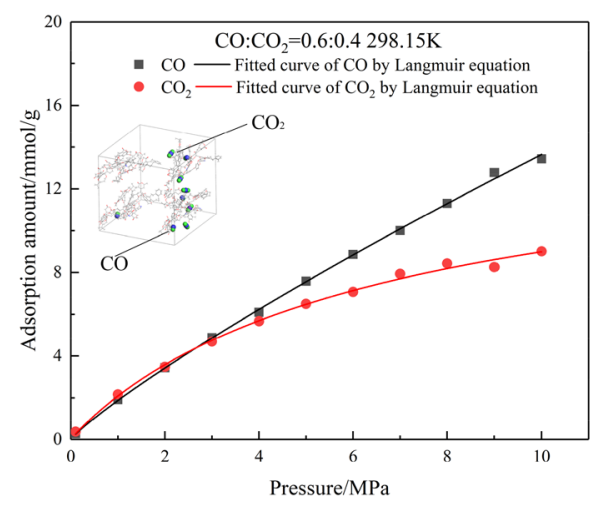

(c) $\mathrm{CO}: \mathrm{CO}_{2}=0.6: 0.4$

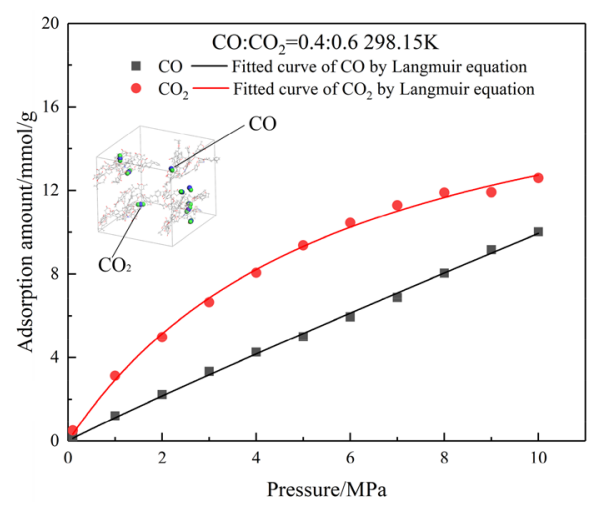

(b) $\mathrm{CO}: \mathrm{CO}_{2}=0.4: 0.6$

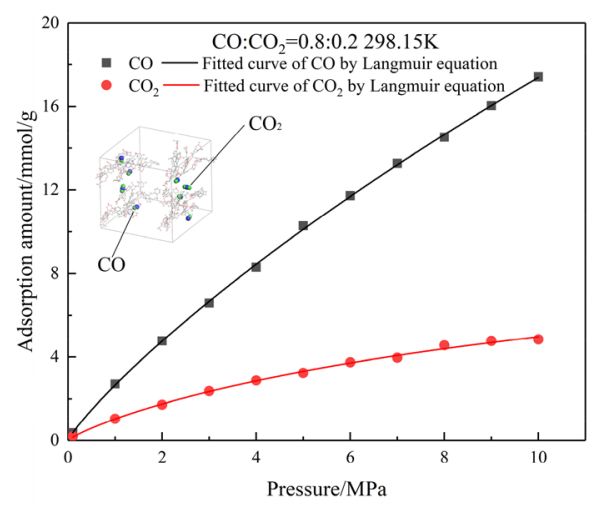

(d) $\mathrm{CO}: \mathrm{CO}_{2}=0.8: 0.2$

Figure 6. Adsorption isotherms of $\mathrm{CO}$ and $\mathrm{CO}_{2}$ at different molar ratios at $298.15 \mathrm{~K}$. 


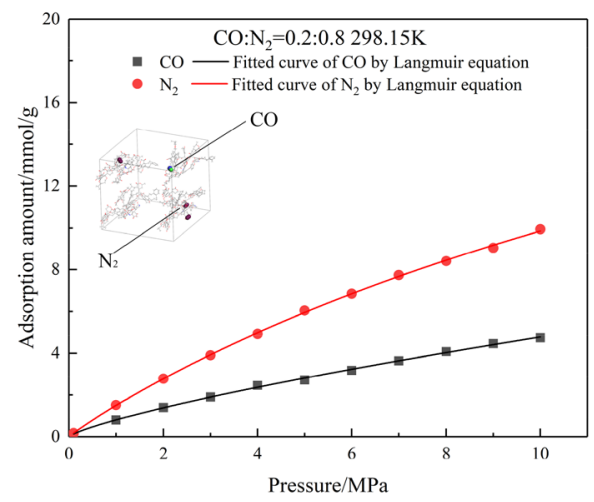

(a) $\mathrm{CO}: \mathrm{N}_{2}=0.2: 0.8$

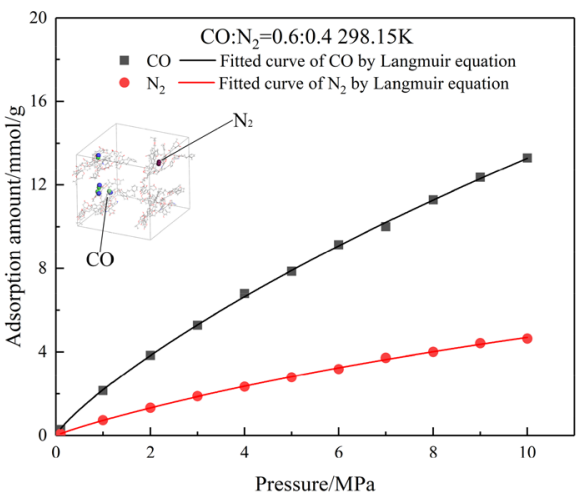

(c) $\mathrm{CO}: \mathrm{N}_{2}=0.6: 0.4$

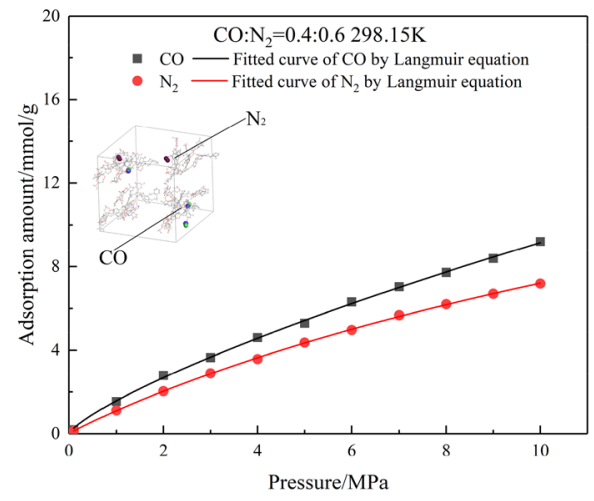

(b) $\mathrm{CO}: \mathrm{N}_{2}=0.4: 0.6$

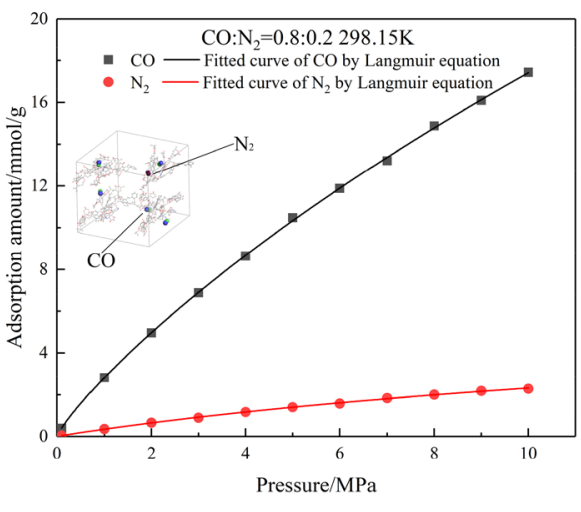

(d) $\mathrm{CO}: \mathrm{N}_{2}=0.8: 0.2$

Figure 7. Adsorption isotherms of $\mathrm{CO}$ and $\mathrm{N}_{2}$ at different molar ratios at $298.15 \mathrm{~K}$.

but also cause the desorption of the original CO in the coal. Therefore, it is also necessary to take fire-prevention measures in mines whose coal seams have a large amount of original $\mathrm{CO}$.

Adsorption isotherms of binary-components. Adsorption isotherms of binary-component of CO and $\mathrm{CO}_{2}$. At a temperature of $298.15 \mathrm{~K}$ and a pressure of $0-10 \mathrm{MPa}, \mathrm{CO}$ and $\mathrm{CO}_{2}$ are mixed at a molar ratio of 0.2:0.8, 0.4:0.6, 0.6:0.4, and 0.8:0.2, and the Langmuir adsorption isotherm obtained is shown in Fig. 6 . It can be seen that the adsorption amount of $\mathrm{CO}$ and $\mathrm{CO}_{2}$ on the lignite molecular supercell has an obvious relationship with the molar ratio of the binary mixture. The competitive adsorption capacity of the two gases is very close. Comparing molar ratio 0.4 and 0.6 of $\mathrm{CO}$, when the pressure is low, the adsorption capacity of $\mathrm{CO}_{2}$ is better than that of CO; comparing molar ratio 0.2 and 0.8 of $\mathrm{CO}$, when the pressure is high, the adsorption capacity of $\mathrm{CO}_{2}$ is inferior to CO.

In the actual production of coal mines, it is generally difficult to reach a high-pressure state in goaf by preinjecting $\mathrm{CO}_{2}$ to prevent fire. Therefore, it is believed that the adsorption capacity of $\mathrm{CO}_{2}$ is greater than that of $\mathrm{CO}$ in actual production. That is, $\mathrm{CO}_{2}$ is not suitable as a fire-fighting gas in coal mines whose coal seams have a large amount of original $\mathrm{CO} . \mathrm{CO}_{2}$ with strong competitive adsorption capacity will occupy the adsorption site, resulting in a large amount of $\mathrm{CO}$ desorption in goaf and diffusion in the working surface.

Adsorption isotherms of binary-component of $\mathrm{CO}$ and $\mathrm{N}_{2}$. At a temperature of $298.15 \mathrm{~K}$ and a pressure of $0-10 \mathrm{MPa}, \mathrm{CO}$ and $\mathrm{N}_{2}$ are mixed at a molar ratio of 0.2:0.8, 0.4:0.6, 0.6:0.4, and 0.8:0.2, and the Langmuir adsorption isotherm obtained is shown in Fig. 7. It can be seen that the adsorption amount of $\mathrm{CO}$ and $\mathrm{N}_{2}$ on the lignite molecular supercell has an obvious relationship with the molar ratio of the binary mixture. The adsorption capacity of $\mathrm{CO}$ is better than that of $\mathrm{N}_{2}$. When the molar ratio is $0.2: 0.8$, the adsorption amount of $\mathrm{N}_{2}$ is greater than that of CO. When the molar ratio of CO is greater than 0.4 , the adsorption amount of CO is significantly higher than that of $\mathrm{N}_{2}$.

In the actual production of coal mines with a large amount of original occurrence $\mathrm{CO}, \mathrm{N}_{2}$ injection is not used as much as possible to prevent fire. Although the adsorption capacity of $\mathrm{N}_{2}$ is lower than that of CO, it will still interfere with the adsorption of $\mathrm{CO}$ and cause part of the $\mathrm{CO}$ to desorb; If the goaf must be pre-injected to prevent fire, the effect of $\mathrm{N}_{2}$ is better than $\mathrm{CO}_{2}$. The relatively weak competitive adsorption capacity of $\mathrm{N}_{2}$ can not only reduce the oxygen concentration in the goaf but also occupy a few adsorption sites. 


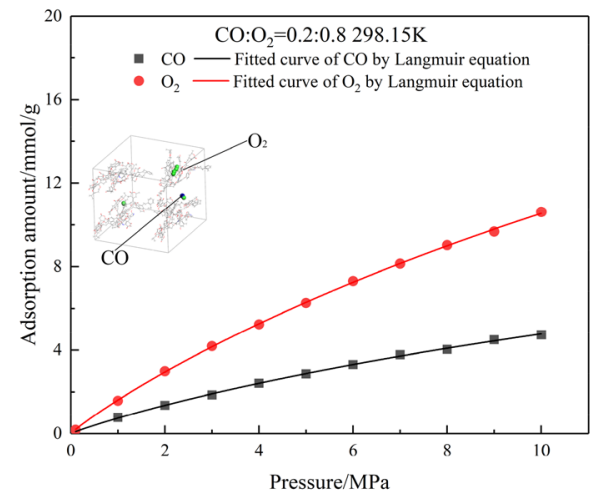

(a) $\mathrm{CO}: \mathrm{O}_{2}=0.2: 0.8$

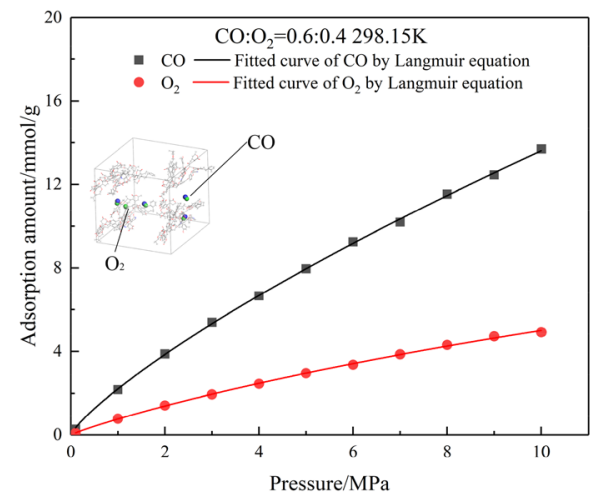

(c) $\mathrm{CO}: \mathrm{O}_{2}=0.6: 0.4$

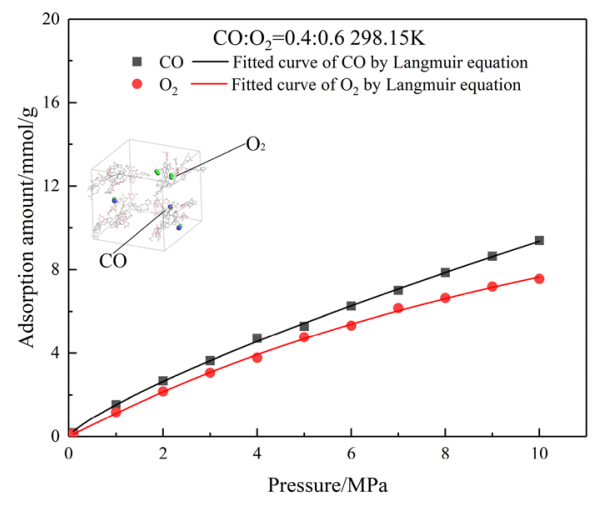

(b) $\mathrm{CO}: \mathrm{O}_{2}=0.4: 0.6$

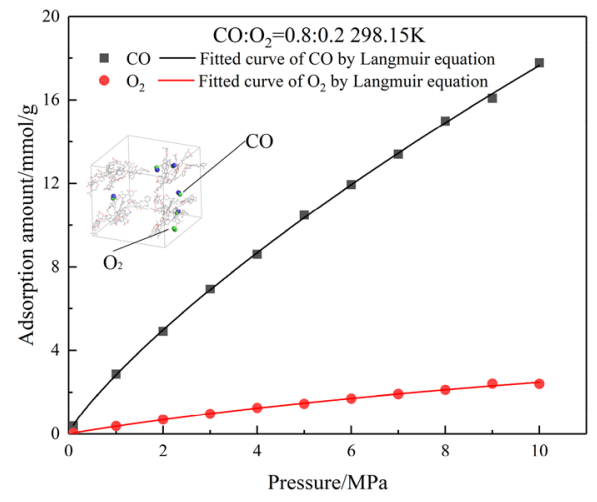

(a) $\mathrm{CO}: \mathrm{O}_{2}=0.8: 0.2$

Figure 8. Adsorption isotherms of $\mathrm{CO}$ and $\mathrm{O}_{2}$ at different molar ratios at $298.15 \mathrm{~K}$.

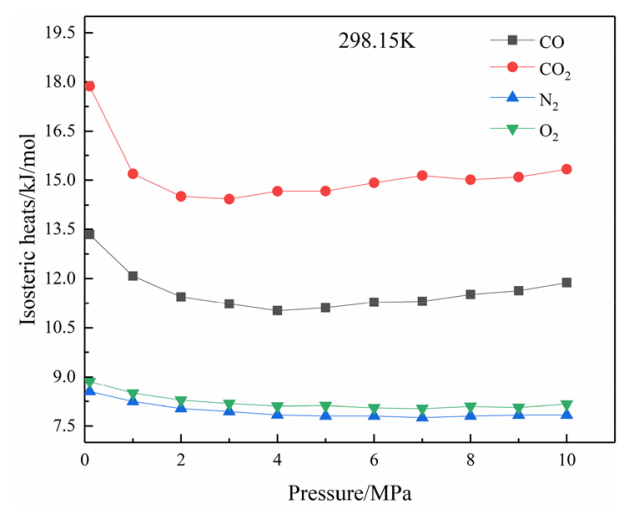

Figure 9. Adsorption isosteric heats of $\mathrm{CO}, \mathrm{CO}_{2}, \mathrm{~N}_{2}$, and $\mathrm{O}_{2}$ at $298.15 \mathrm{~K}$.

Adsorption isotherms of binary-component of $\mathrm{CO}$ and $\mathrm{O}_{2}$. At a temperature of $298.15 \mathrm{~K}$ and a pressure of 0-10 MPa, $\mathrm{CO}$ and $\mathrm{O}_{2}$ are mixed at a molar ratio of 0.2:0.8, 0.4:0.6, 0.6:0.4, and 0.8:0.2, and the Langmuir adsorption isotherms obtained are shown in Fig. 8. It can be seen that the result is similar to $\mathrm{CO}$ and $\mathrm{N}_{2}$ on the lignite molecular supercell. The adsorption capacity of $\mathrm{CO}$ is better than that of $\mathrm{O}_{2}$. When the molar ratio is $0.2: 0.8$, the adsorption amount of $\mathrm{O}_{2}$ is higher than that of $\mathrm{CO}$; When the $\mathrm{CO}$ molar ratio is greater than 0.4 , the $\mathrm{CO}$ adsorption amount is significantly higher than $\mathrm{O}_{2}$.

In the actual production of coal mines with a large amount of original $\mathrm{CO}$, the air leakage control at the working faces and other locations should be strengthened to reduce fresh air entering the goafs. Although the adsorption capacity of $\mathrm{O}_{2}$ is not as good as that of $\mathrm{CO}$, it will still interfere with the adsorption of $\mathrm{CO}$ and cause some CO to desorb. 


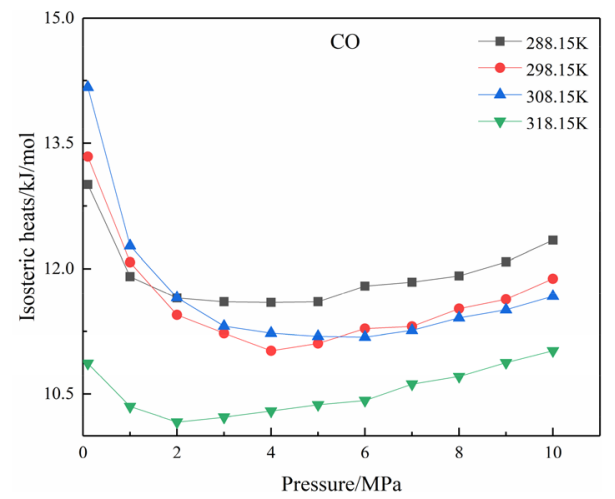

Figure 10. Adsorption isosteric heats of $\mathrm{CO}$ at $288.15-318.15 \mathrm{~K}$.

Single-component adsorption isosteric heats. The isosteric heat of adsorption reflects the strength of the interaction between adsorbate and adsorbent. The higher the isosteric heat of adsorption, the stronger the interaction between adsorbate and adsorbent. When the isosteric heat of adsorption is less than $41.84 \mathrm{~kJ} / \mathrm{mol}$, the adsorption form is only physical adsorption, no chemical adsorption. When the temperature is $298.15 \mathrm{~K}$ and the pressure is $0-10 \mathrm{MPa}$, the isosteric heats of adsorption of $\mathrm{CO}, \mathrm{CO}_{2}, \mathrm{~N}_{2}$, and $\mathrm{O}_{2}$ are shown in Fig. 9. As the pressure increases, the adsorption heat of each gas first decreases and then increases, but the maximum value is still at the lowest pressure $(0.1 \mathrm{MPa})$ and less than $41.84 \mathrm{~kJ} / \mathrm{mol}$, indicating that each gas is adsorbed at the initial pressure and has the strongest interaction with coal, and there is no chemical adsorption. The isosteric heat of $\mathrm{CO}$ adsorption at temperatures of $288.15,298.15,308.15$, and $318.15 \mathrm{~K}$ and pressure $0-10 \mathrm{MPa}$ is shown in Fig. 10. It can be seen that in the pressure $0-2 \mathrm{MPa}$ and the temperature $308.15 \mathrm{~K}$, the isosteric heat of adsorption is the largest, and $\mathrm{CO}$ has the strongest interaction with coal; in the pressure 2-10 MPa, when the temperature is $288.15 \mathrm{~K}$, the isosteric heat of adsorption is the largest, and CO has the strongest interaction with coal; when the temperature is $318.15 \mathrm{~K}$, the isosteric heat of adsorption is always smallest, which further shows that high temperature is not conducive to $\mathrm{CO}$ adsorption, that is, it will cause $\mathrm{CO}$ desorption.

\section{Conclusion}

(1) Lignite molecules have different structures at different temperatures. In this paper, the lignite molecules are annealed and optimized at the normal temperature range $(288.15,298.15,308.15$, and $318.15 \mathrm{~K})$ of working surfaces, and the lignite unit cell structure under the temperature step is obtained. Through the adsorption study of $\mathrm{CO}, \mathrm{CO}_{2}, \mathrm{~N}_{2}$, and $\mathrm{O}_{2}$, the Langmuir equation of adsorption capacity and pressure load was found. The order of adsorption capacity of different gases at 0-10 MPa pressure is $\mathrm{CO}_{2}>\mathrm{CO}>\mathrm{O}_{2}>\mathrm{N}_{2}$.

(2) For the $\mathrm{CO} / \mathrm{CO}_{2}$ binary-components, the competitive adsorption capacity of $\mathrm{CO}_{2}$ is stronger than that of $\mathrm{CO}$; for the $\mathrm{CO} / \mathrm{N}_{2}$ and $\mathrm{CO} / \mathrm{O}_{2}$ binary-components, even if the molar ratio of $\mathrm{N}_{2}$ or $\mathrm{O}_{2}$ reaches 0.6 , its adsorption capacity is still significantly smaller than that of $\mathrm{CO}$, indicating that the competitive adsorption of $\mathrm{CO}$ in the binary-component is stronger than that of $\mathrm{N}_{2}$ or $\mathrm{O}_{2}$.

(3) For coal seams with a large amount of original CO, coal mines should adopt other measures to prevent fires in goafs, such as grouting. It is best not to use $\mathrm{N}_{2}$ or $\mathrm{CO}_{2}$ injection to prevent fires. At the same time, air leakage control in goafs should be strengthened. To prevent $\mathrm{CO}_{2}, \mathrm{~N}_{2}$, and $\mathrm{O}_{2}$ from occupying adsorption sites and prevent the oxidation and heating of the residual coal, so that prevent the adsorbed $\mathrm{CO}$ in residual coal from desorbing and diffusing to the work face.

\section{Data availability}

All data generated or analysed during this study are included in this published article (and its Supplementary Information files).

Received: 10 April 2021; Accepted: 24 May 2021

Published online: 03 June 2021

\section{References}

1. Goldbaum, L., Orellano, T. \& Dergal, E. Mechanism of the toxic action of carbon monoxide. Ann. Clin. Lab. Sci. 6, 372-376 (1976).

2. Zhou, L., Yuan, L., Bahrami, D., Thomas, R. A. \& Rowland, J. H. Numerical and experimental investigation of carbon monoxide spread in underground mine fires. J. Fire Sci. 36, 406-418 (2018).

3. Zhuo, H., Qin, B., Qin, Q. \& Su, Z. Modeling and simulation of coal spontaneous combustion in a gob of shallow buried coal seams. Process Saf. Environ. Prot. 131, 246-254 (2019).

4. Wen, H., Yu, Z., Fan, S., Zhai, X. \& Liu, W. Prediction of spontaneous combustion potential of coal in the gob area using CO extreme concentration: A case study. Combust. Sci. Technol. 189, 1713-1727 (2017).

5. Wieckowski, M., Howaniec, N. \& Smolinski, A. Natural desorption of carbon monoxide during the crushing of coal simulating natural rock mass pressure. Sci. Total. Environ. 736, 139639. https://doi.org/10.1016/j.scitotenv.2020.139639 (2020). 
6. Wang, Y., Liu, D., Cai, Y. \& Li, X. Variation of petrophysical properties and adsorption capacity in different rank coals: An experimental study of coals from the Junggar, Ordos and Qinshui Basins in China. Energies 12, 986 (2019).

7. Nie, B., Liu, X., Yang, L., Meng, J. \& Li, X. Pore structure characterization of different rank coals using gas adsorption and scanning electron microscopy. Fuel 158, 908-917 (2015).

8. Chen, S. et al. Pore structure characterization of different rank coals using $\mathrm{N}_{2}$ and $\mathrm{CO}_{2}$ adsorption and its effect on $\mathrm{CH}_{4}$ adsorption capacity: A case in Panguan syncline, western Guizhou, China. Energy Fuels 31, 6034-6044 (2017).

9. Liu, Y., Zhu, Y., Liu, S., Li, W. \& Tang, X. Temperature effect on gas adsorption capacity in different sized pores of coal: Experiment and numerical modeling. J. Pet. Sci. Eng. 165, 821-830 (2018).

10. Zhang, Z.-G. et al. Effect of moisture content on methane adsorption-and desorption-induced deformation of tectonically deformed coal. Adsorp. Sci. Technol. 36, 1648-1668 (2018).

11. Dang, Y. et al. Molecular simulation of $\mathrm{CO}_{2} / \mathrm{CH}_{4}$ adsorption in brown coal: Effect of oxygen-, nitrogen-, and sulfur-containing functional groups. Appl. Surf. Sci. 423, 33-42 (2017).

12. Tang, X. \& Ripepi, N. High pressure supercritical carbon dioxide adsorption in coal: Adsorption model and thermodynamic characteristics. J. Catal. 18, 189-197 (2017).

13. Meng, M. et al. Adsorption characteristics of supercritical $\mathrm{CO}_{2} / \mathrm{CH}_{4}$ on different types of coal and a machine learning approach. Chem. Eng. J. 368, 847-864 (2019).

14. Zhang, J., Clennell, M., Dewhurst, D. \& Liu, K. Combined Monte Carlo and molecular dynamics simulation of methane adsorption on dry and moist coal. Fuel 122, 186-197 (2014).

15. Wu, S., Deng, C. \& Wang, X. Molecular simulation of flue gas and CH4 competitive adsorption in dry and wet coal. J. Nat. Gas Sci. Eng. 71, 102980 (2019).

16. Zhou, W., Wang, H., Zhang, Z., Chen, H. \& Liu, X. Molecular simulation of $\mathrm{CO}_{2} / \mathrm{CH}_{4} / \mathrm{H}_{2} \mathrm{O}$ competitive adsorption and diffusion in brown coal. RSC Adv. 9, 3004-3011 (2019).

17. Yu, S., Bo, J. \& Wu, L. Molecular simulation of $\mathrm{CH}_{4} / \mathrm{CO}_{2} / \mathrm{H}_{2} \mathrm{O}$ competitive adsorption on low rank coal vitrinite. Phys. Chem. Chem. Phys. 19, 17773-17788 (2017).

18. Gao, D., Hong, L., Wang, J. \& Zheng, D. Molecular simulation of gas adsorption characteristics and diffusion in micropores of lignite. Fuel 269, 117443 (2020).

19. Zhu, H., Chang, M. \& Wang, H. Study on primal CO gas generation and emission of coal seam. Int. J. Min. Sci. Technol. 27, 973-979 (2017).

20. Zhang, J., Guo, L., Zhou, X. \& Wang, Y. Effect of inertinite and vitrinite of coal samples on carbon monoxide absorption by coal seams. J. China Coal Soc. 12, 32 (2007).

21. Sharma, A., Namsani, S. \& Singh, J. K. Molecular simulation of shale gas adsorption and diffusion in inorganic nanopores. Mol. Simul. 41, 414-422 (2015).

22. Lin, K. \& Zhao, Y.-P. Entropy and enthalpy changes during adsorption and displacement of shale gas. Energy 221, 119854 (2021).

23. Lin, K., Yuan, Q., Zhao, Y.-P. \& Cheng, C. Which is the most efficient candidate for the recovery of confined methane: Water, carbon dioxide or nitrogen?. Extreme Mech. Lett. 9, 127-138 (2016).

24. Lin, K., Yuan, Q. \& Zhao, Y.-P. Using graphene to simplify the adsorption of methane on shale in MD simulations. Comput. Mater. Sci. 133, 99-107 (2017).

25. Lin, K., Huang, X. \& Zhao, Y.-P. Combining image recognition and simulation to reproduce the adsorption/desorption behaviors of shale gas. Energy Fuels 34, 258-269 (2019).

26. Wang, H., Qu, Z., Bai, J. \& Qiu, Y. Combined grand canonical Monte Carlo and finite volume method simulation method for investigation of direct air capture of low concentration $\mathrm{CO}_{2}$ by $5 \mathrm{~A}$ zeolite adsorbent bed. Int. J. Heat Mass Transf. 126, 1219-1235 (2018).

27. Li, X. et al. Charge-modulated $\mathrm{CO}_{2}$ capture of $\mathrm{C}_{3} \mathrm{~N}$ nanosheet: Insights from DFT calculations. Chem. Eng. J. 338, 92-98 (2018).

28. Li, X. et al. Superior selective $\mathrm{CO}_{2}$ adsorption of $\mathrm{C}_{3} \mathrm{~N}$ pores: GCMC and DFT simulations. ACS Appl. Mater. Interfaces 9 , 3116131169 (2017).

29. Zhu, H. et al. Molecular simulation study on adsorption and diffusion behaviors of $\mathrm{CO}_{2} / \mathrm{N}_{2}$ in lignite. ACS Omega 5, 29416-29426 (2020).

30. Huang, X., Zhao, Y.-P., Wang, X. \& Pan, L. Adsorption-induced pore blocking and its mechanisms in nanoporous shale due to interactions with supercritical $\mathrm{CO}_{2}$. J. Pet. Sci. Eng. 178, 74-81 (2019).

31. Huang, X. \& Zhao, Y.-P. Characterization of pore structure, gas adsorption, and spontaneous imbibition in shale gas reservoirs. J. Pet. Sci. Eng. 159, 197-204 (2017).

32. Peng, D.-Y. \& Robinson, D. B. A new two-constant equation of state. Ind. Eng. Chem. Res. 15, 59-64 (1976).

33. Shugang, L., Yang, B., Haifei, L., Min, Y. \& Hang, L. Molecular simulation of adsorption thermodynamics of multicomponent gas in coal. J. China Coal Soc. 43, 2476-2483 (2018).

34. Mayo, S. L., Olafson, B. D. \& Goddard, W. A. DREIDING: A generic force field for molecular simulations. J. Phys. chem. 94, 8897-8909 (1990).

35. Takanohashi, T., Iino, M. \& Nakamura, K. Simulation of interaction of coal associates with solvents using the molecular dynamics calculation. Energy Fuels 12, 1168-1173 (1998).

36. Karasawa, N. \& Goddard, W. A. III. Force fields, structures, and properties of poly (vinylidene fluoride) crystals. Macromolecules 25, 7268-7281 (2002).

37. Qiao, L., Deng, C. \& Fan, Y. Numerical simulation study on $\mathrm{CO}_{2}$ storage in coalbed. Energy Sources Part A 42, 446-459 (2020).

38. Fan, N. et al. Numerical study on enhancing coalbed methane recovery by injecting $\mathrm{N}_{2} / \mathrm{CO}_{2}$ mixtures and its geological significance. Energy Sci. Eng. 8, 1104-1119 (2020).

\section{Acknowledgements}

This project is supported by the National Natural Science Foundation of China (Grant No. 51574143 and No. 51974149).

\section{Author contributions}

J.Z.: Conceptualization, Software, Original draft writing; J.W. \& C.Z.: Review \& Editing, Funding acquisition; Z.L.: Review \& Editing, Resources; J.Z. \& B.L.: Review.

\section{Competing interests}

The authors declare no competing interests.

\section{Additional information}

Supplementary Information The online version contains supplementary material available at https://doi.org/ 10.1038/s41598-021-91197-0. 
Correspondence and requests for materials should be addressed to J.Z.

Reprints and permissions information is available at www.nature.com/reprints.

Publisher's note Springer Nature remains neutral with regard to jurisdictional claims in published maps and institutional affiliations.

(c) (i) Open Access This article is licensed under a Creative Commons Attribution 4.0 International cc) License, which permits use, sharing, adaptation, distribution and reproduction in any medium or format, as long as you give appropriate credit to the original author(s) and the source, provide a link to the Creative Commons licence, and indicate if changes were made. The images or other third party material in this article are included in the article's Creative Commons licence, unless indicated otherwise in a credit line to the material. If material is not included in the article's Creative Commons licence and your intended use is not permitted by statutory regulation or exceeds the permitted use, you will need to obtain permission directly from the copyright holder. To view a copy of this licence, visit http://creativecommons.org/licenses/by/4.0/.

(C) The Author(s) 2021 